\title{
Speciated atmospheric mercury in the marine boundary layer of the Bohai Sea and Yellow Sea
}

\author{
Chunjie Wang a, b, Zhijia Ci ${ }^{\text {a }}$, Zhangwei Wang ${ }^{\text {a, * }}$, Xiaoshan Zhang ${ }^{\text {a }}$, Jia Guo ${ }^{\text {a }}$ \\ ${ }^{a}$ Research Center for Eco-Environmental Sciences, Chinese Academy of Sciences, No. 18 Shuangqing Road, Beijing 100085, China \\ ${ }^{\mathrm{b}}$ Graduate School of Chinese Academy of Sciences, Beijing 100049, China
}

\section{H I G H L I G H T S}

- Atmospheric $\mathrm{Hg}$ (GEM, RGM, and $\mathrm{Hg}^{\mathrm{P}}{ }_{2.5}$ ) were determined in the East Asia MBL.

- $\mathrm{Hg}^{\mathrm{P}}{ }_{2.5}$ concentrations in the offshore area were higher than those in the open sea.

- GEM and $\mathrm{Hg}^{\mathrm{P}}{ }_{2.5}$ levels over the BS were higher than those over the YS.

- RGM showed a homogeneous distribution both in spring and fall.

- RGM was correlated well with air temperature but inversely correlated with RH.

\section{A R T I C L E I N F O}

\section{Article history:}

Received 26 November 2015

Received in revised form

4 February 2016

Accepted 14 February 2016

Available online 16 February 2016

\section{Keywords:}

Gaseous elemental mercury

Reactive gaseous mercury

Fine particulate mercury

Marine boundary layer

\begin{abstract}
A B S T R A C T
The objectives of this study are to identify the spatial and temporal distributions of gaseous elemental mercury (GEM), reactive gaseous mercury (RGM), and fine particulate mercury $\left(\operatorname{Hg}^{\mathrm{P}} 2.5\right)$ in the marine boundary layer (MBL) of the Bohai Sea (BS) and Yellow Sea (YS), and to investigate the relationships between mercury species and meteorological parameters. The mean concentrations of GEM, RGM, and $\mathrm{Hg}^{\mathrm{P}} 2.5$ were $2.03 \mathrm{ng} \mathrm{m}^{-3}, 2.5 \mathrm{pg} \mathrm{m}^{-3}$, and $8.2 \mathrm{pg} \mathrm{m}^{-3}$ in spring, and $2.09 \mathrm{ng} \mathrm{m}^{-3}, 4.3 \mathrm{pg} \mathrm{m}^{-3}$, and $8.3 \mathrm{pg} \mathrm{m}^{-3}$ in fall. Reactive mercury ( $\mathrm{RGM}+\mathrm{Hg}^{\mathrm{P}}{ }_{2.5}$ ) represented $<1 \%$ of total atmospheric mercury $\left(\mathrm{GEM}+\mathrm{RGM}+\mathrm{Hg}^{\mathrm{P}} 2.5\right)$, which indicated that most mercury export in the MBL was GEM and the direct outflow of reactive mercury was very small. Moreover, GEM concentrations over the BS were generally higher than those over the YS both in spring and fall. Although RGM showed a homogeneous distribution over the BS and YS both in spring and fall, the mean RGM concentration in fall was significantly higher than that in spring. In contrast, the spatial distribution of $\mathrm{Hg}^{\mathrm{P}} 2.5$ generally reflected a gradient with high levels near the coast of China and low levels in the open sea, suggesting the significant atmospheric mercury outflow from China. Interestingly, the mean RGM concentrations during daytime were significantly higher than those during nighttime both in spring and fall, while the opposite results were observed for $\mathrm{Hg}^{\mathrm{P}} 2.5$. Additionally, RGM positively correlates with air temperature while negatively correlates with relative humidity. In conclusion, the elevated atmospheric mercury levels in the BS and YS compared to other open seas suggested that the human activities had a significant influence on the oceanic mercury cycle downwind of China.
\end{abstract}

() 2016 Elsevier Ltd. All rights reserved.

\section{Introduction}

The special characteristics of mercury $(\mathrm{Hg})$, such as the longrange atmospheric transport, transformation and biomagnification, and the role as a neurotoxin, make it a ubiquitous,

\footnotetext{
* Corresponding author.

E-mail address: wangzhw@rcees.ac.cn (Z. Wang).
}

potent, and persistent pollutant of global concern (Schroeder and Munthe, 1998; Wang and Pehkonen, 2004). Hg is emitted into the atmosphere in different chemical and physical forms from a variety of natural (e.g., oceans, land, biomass burning, and volcanoes) (Ferrara et al., 2000; Pirrone et al., 2010; Strode et al., 2007) and anthropogenic sources (e.g., fossil fuel combustion, metal production, cement production, and waste incineration) (Pacyna et al., 2003, 2006, 2010; Pirrone et al., 2010; Schroeder and Munthe, 1998; Zhang et al., 2015). Once $\mathrm{Hg}$ is released into the 
atmosphere, its physical and chemical properties and transformation processes will determine its subsequent fate and transport. Hg can be transformed from one species to another via photooxidation, photo-reduction, reactions with halides, and other oxidation or reduction reactions (Choi et al., 2008).

$\mathrm{Hg}$ in the atmosphere exists in three major operationally defined forms: gaseous elemental $\mathrm{Hg}\left(\mathrm{GEM}\right.$ or $\mathrm{Hg}^{0}$ ), reactive gaseous $\mathrm{Hg}(\mathrm{RGM})$, and particulate $\mathrm{Hg}\left(\mathrm{Hg}^{\mathrm{P}}\right)$ (Schroeder and Munthe, 1998). Each Hg species behaves differently in the atmosphere depending on their different physicochemical characteristics. Generally, more than $95 \%$ of the total atmospheric $\mathrm{Hg}$ $\left(\mathrm{TAM}=\mathrm{GEM}+\mathrm{RGM}+\mathrm{Hg}^{\mathrm{P}}\right)$ is presented as GEM, which is very stable in the atmosphere with a residence time of $0.3-1$ year due to its high volatility, low solubility, and chemical stability (Radke et al., 2007; Selin et al., 2007; Weiss-Penzias et al., 2003). This enables GEM to undergo a long-range transport and makes it well-mixed on a global scale. The atmospheric lifetime of RGM is shorter (hours to several days) than that of GEM due to its higher solubility and lower volatility (Holmes et al., 2009; Laurier and Mason, 2007). The composition of $\mathrm{RGM}$ (e.g., $\mathrm{HgBr}_{2}, \mathrm{HgCl}_{2}, \mathrm{HgBrOH}$ ) varies across space and time (Gustin et al., 2015). The lifetime of $\mathrm{Hg}^{\mathrm{P}}$ is on the order of a day or week depending on the diameter of the particulate. The shorter atmospheric lifetime of RGM and $\mathrm{Hg}^{\mathrm{P}}$ indicates that they are more rapidly deposited on local to regional scales through both wet and dry deposition. Therefore, Hg speciation determinates its fate and transport in the atmosphere. RGM and $\mathrm{Hg}^{\mathrm{P}}$ play an important role in $\mathrm{Hg}$ deposition though they generally account for $<5 \%$ of TAM, and atmospheric Hg (mainly RGM and $\mathrm{Hg}^{\mathrm{P}}$ ) deposition is identified as the dominant source of $\mathrm{Hg}$ to the ocean (Holmes et al., 2009; Mason and Sheu, 2002; Mason et al., 2012).

Atmospheric $\mathrm{Hg}$ emissions from East Asia were much higher than those from other continents in global emission inventories (Pacyna and Pacyna, 2002; Pacyna et al., 2006; 2010). Current estimates suggest that over $50 \%$ of the global anthropogenic $\mathrm{Hg}$ emissions are from Asia (Lin et al., 2010; Pacyna and Pacyna, 2002; Pacyna et al., 2006, 2010), while approximately 40\% of the anthropogenic $\mathrm{Hg}$ in China is emitted in the forms of RGM and $\mathrm{Hg}^{\mathrm{P}}$ (Zhang et al., 2015; Streets et al., 2005). China is the largest contributor to global atmospheric $\mathrm{Hg}$, where anthropogenic $\mathrm{Hg}$ emissions are likely to further increase with the expansion of nonferrous production and coal combustion (Streets et al., 2005; Wu et al., 2006; Zhang et al., 2015). Higher Hg emissions in China may result in elevated atmospheric Hg concentrations and deposition levels, and then cause $\mathrm{Hg}$ pollution in the surrounding regions. But we have little knowledge on the atmospheric $\mathrm{Hg}$ speciation in the East Asia marine boundary layer (MBL).

Recently, speciated atmospheric Hg concentrations have been monitored at many locations with various site characteristics, such as remote oceans, Arctic and Antarctic, coastal, rural, and urban sites (Chand et al., 2008; Cheng et al., 2012, 2013a,b, 2014; Choi et al., 2008; Fu et al., 2011, 2012; Gabriel et al., 2005; Kim et al., 2009; Laurier and Mason, 2007; Liu et al., 2007, 2011, 2010; Soerensen et al., 2010; Valente et al., 2007; Wan et al., 2009; Xu et al., 2015; Zhang et al., 2012). However, study on the knowledge of the speciated atmospheric Hg over the East Asia MBL is limited. The objectives of this study are to characterize the levels of atmospheric Hg species as well as their spatial distributions in the MBL of the Bohai Sea (BS) and Yellow Sea (YS), and to ascertain the relationships between $\mathrm{Hg}$ species and meteorological parameters. Findings from this investigation are discussed in terms of better understanding the behavior and cycling of atmospheric $\mathrm{Hg}$ in the MBL.

\section{Materials and methods}

\subsection{Study area}

The study area includes the BS and YS, which is located in the downwind of the East Asia. The BS is an inner sea with an average depth of $18 \mathrm{~m}$, which is surrounded by numerous economicallydeveloped and industrialized provinces, such as Shandong, Liaoning, Hebei, Tianjin, and Beijing (Fig. 1). The low rate of water exchange favors the accumulation of pollutants in the BS. The YS is a semi-enclosed and representative shallow continental shelf sea located between mainland China and the Korean Peninsula (Fig. 1). For these reasons, the BS and YS are particularly vulnerable to anthropogenic pollutants originated from industrialized and densely populated East Asia. Hg enters the BS and YS through terrestrial runoff from the rivers (e.g., Yellow, Liao, Luanhe, Haihe, Yalu, Han, Taedong, and Geum Rivers) and atmospheric wet and dry deposition. Hg and its compounds may have a toxic impact on the ecosystem of these marine environments.

\subsection{Experimental methods}

Two open cruises were organized by Ocean University of China (OUC), and conducted from 27 April to 20 May 2014 (spring) and from 5 to 24 November 2014 (fall), respectively. The two expeditions (spring: Fig. 2a and fall: Fig. 2b) covered the majority areas of the BS and YS between latitudes $31^{\circ} \mathrm{N}$ and $40^{\circ} \mathrm{N}$ and longitudes $118^{\circ} \mathrm{E}$ and $125^{\circ} \mathrm{E}$. The data and samples were collected onboard the $\mathrm{R} / \mathrm{V}$ DongfanghongII (OUC). In this study, meteorological parameters, including wind speed, air temperature, and relative humidity $(\mathrm{RH})$, were measured synchronously with GEM.

\subsubsection{Atmospheric GEM measurements}

GEM in the marine atmosphere was continuously measured using an automatic dual channel, single amalgamation cold vapor atomic fluorescence analyzer (Model 2537B, Tekran ${ }^{\circledR}$, Inc., Toronto, Canada) with a $0.2 \mu \mathrm{m}$ Teflon filter and a soda-lime trap just

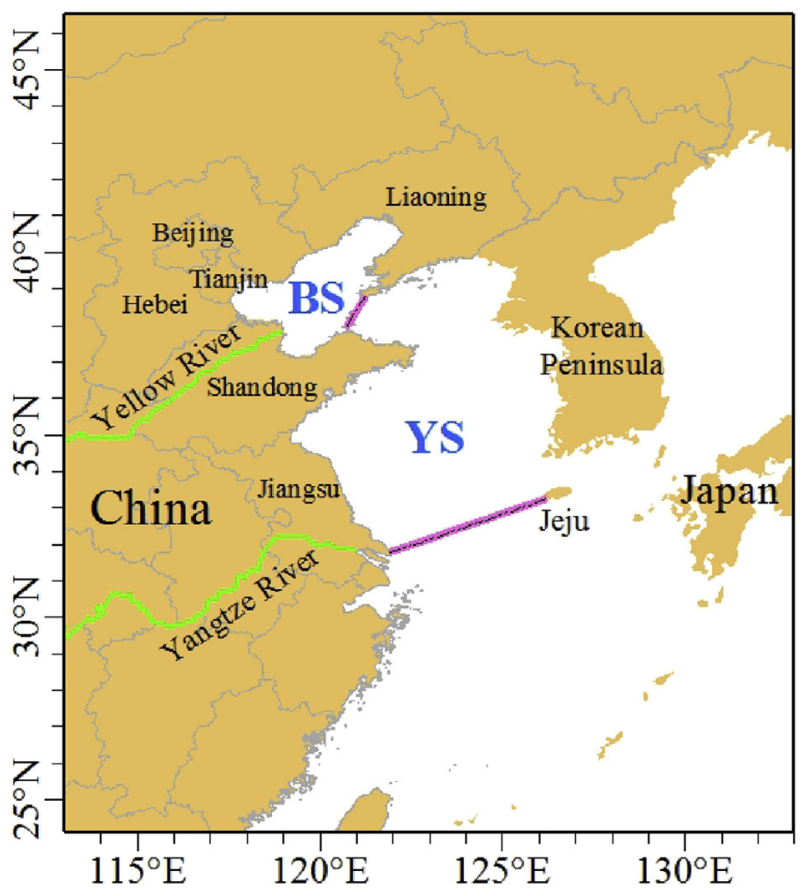

Fig. 1. Location of the study area, including the BS and YS. 

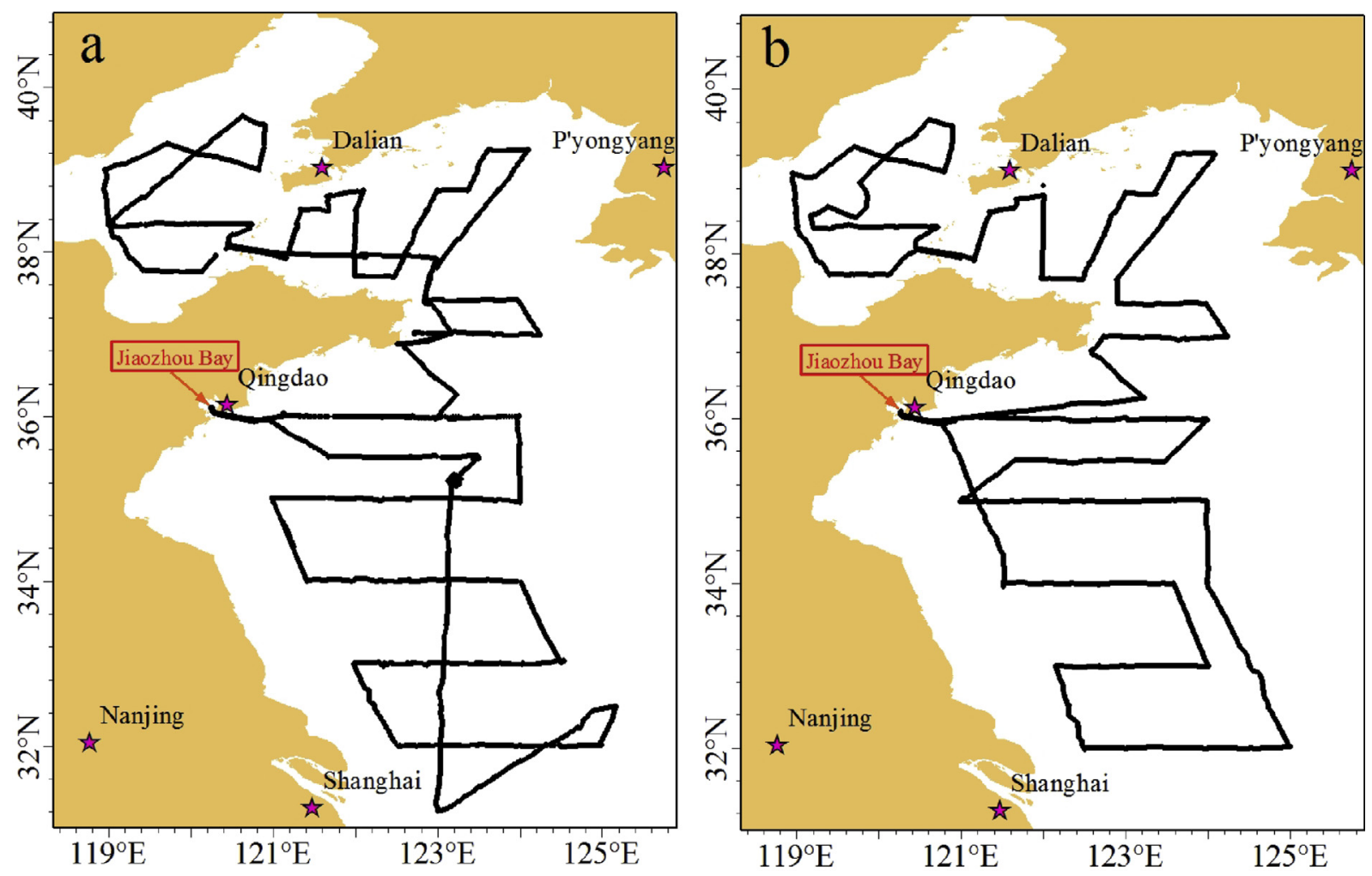

Fig. 2. Cruise tracks (black line) of the R/V during the spring (a) and fall (b) of 2014.

upstream to remove the atmospheric particulates and water. The soda lime was changed every 3 days during the cruises. The Tekran ${ }^{\circledR}$ instrument is based on the collection of $\mathrm{Hg}^{0}$ amalgamation on gold traps, followed by thermal desorption and then detection of $\mathrm{Hg}^{0}$ by cold vapor atomic fluorescence spectrometry (CVAFS) (Tekran, 2008). In this study, 5-min sampling interval was conducted with an air flow rate of $1.51 \mathrm{~min}^{-1}$. The detection limit of GEM was less than $0.1 \mathrm{ng} \mathrm{m}^{-3}$.

\subsubsection{Sampling of atmospheric RGM and $\mathrm{Hg}^{\mathrm{P}}$}

The RGM and $\mathrm{Hg}^{\mathrm{P}}$ were sampled using a manual system, which has been described in detail by Landis et al. (2002). The unit includes two $\mathrm{KCl}$-coated quartz annular denuders, a $47 \mathrm{~mm}$ Teflon filter holder (URG Corporation), and a pump etc. (Landis et al., 2002; Liu et al., 2011). The $\mathrm{Hg}^{\mathrm{P}}$ measured in this study was the $\mathrm{Hg}$ content in fine particulate matters (hereafter referred to as $\mathrm{Hg}^{\mathrm{P}}$ 2.5). The quartz annular denuders were cleaned, coated, and conditioned prior to RGM sampling with a flow rate of $101 \mathrm{~min}^{-1}$ (Landis et al., 2002). The $\mathrm{Hg}^{\mathrm{P}}{ }_{2.5}$ samples were collected on quartz fiber filter ( $47 \mathrm{~mm}$ diameter, Whatman) housed in quartz denuders because the quartz filter had been widely used to collect $\mathrm{Hg}^{\mathrm{P}}$ in the previous studies (Kim et al., 2012; Landis et al., 2002; Liu et al., 2011). The manual system for RGM and $\mathrm{Hg}^{\mathrm{P}} 2.5$ traps were positioned vertically, and the inlet was located at the front deck $1.3 \mathrm{~m}$ above the top deck of the $\mathrm{R} / \mathrm{V}$. During sampling, denuders were maintained at $20-30{ }^{\circ} \mathrm{C}$ above the ambient air temperature using a heating sleeve to prevent hydrolysis of the $\mathrm{KCl}$ coating surface as well as ensure quantitative transport of air through the inlet. Approximately $11-12 \mathrm{~h} \mathrm{Hg}^{\mathrm{P}} 2.5$ samples were collected each day from 6:00 to 18:00 (daytime) and from 18:00 to 6:00 (next day) (nighttime) with a resulting sample volume of $6.6-7.2 \mathrm{~m}^{3}$, but the RGM samples were collected every $6 \mathrm{~h}$ (6:00-12:00 and 12:00-18:00, local time) during daytime and $12 \mathrm{~h}$ during nighttime. These campaigns were conducted to investigate the difference in phase partitioning and cycling of RGM and $\operatorname{Hg}^{\mathrm{P}} 2.5$ between day and night.

\subsubsection{Analysis of atmospheric RGM and $\mathrm{Hg}^{\mathrm{P}} 2.5$}

Upon completion of the sampling, the $\mathrm{KCl}$ coated annular denuder was thermally desorbed in a tube furnace (Model BTF1200 C-S, Anhui BEQ Equipment Technology Co., Ltd, China) used at $500{ }^{\circ} \mathrm{C}$ for RGM. A soda lime trap was used to protect the gold traps (Tekran ${ }^{\circledR}$ 2537B) from being passivated by non-Hg compound(s) collected by the denuder (Landis et al., 2002), and the resulting thermally decomposed $\mathrm{Hg}^{0}$ in carrier gas (zero air, i.e. $\mathrm{Hg}$ free air) was quantified using the Tekran ${ }^{\circledR}$ instrument. The analysis procedures employed for RGM pyrolysis were described by Landis et al. (2002). The method detection limit was calculated to be $0.90 \mathrm{pg} \mathrm{m}^{-3}$ for RGM based on 3 times the standard deviation of the blanks $(\mathrm{n}=110)$ for the whole dataset, which was comparable to that measured by Liu et al. (2011). The third reading during the zero air flush at the beginning of every desorbing cycle was used as the system blank (Liu et al., 2007; Xu et al., 2015). All RGM concentrations presented in this study were blank corrected.

While after sampling, the preservation and analysis methods for $\mathrm{Hg}^{\mathrm{P}}$ have been described in our previous study (Wang et al., 2016). The average blank value $(n=6)$ was $3.4 \mathrm{pg}$ of $\mathrm{Hg}$ per filter (equivalent of $<0.5 \mathrm{pg} \mathrm{m}^{-3}$ for a $12 \mathrm{~h}$ sample) in this study. The average field blank was subtracted from the samples. The detection limit was less than $1.5 \mathrm{pg} \mathrm{m}^{-3}$ based on 3 times the standard deviation of field blanks $(n=6)$. A recent work has suggested that the filter-based $\mathrm{Hg}^{\mathrm{P}}$ has minimal positive artifact from uptake of RGM during sampling (Talbot et al., 2011). However, it is important to note that there are still some artifacts associated with $\mathrm{Hg}^{\mathrm{P}}$ collection and interferences with the collection of RGM on $\mathrm{KCl}$ coated denuders (Gustin et al., 2015; Lyman et al., 2010; Malcolm and 
Keeler, 2007; Rutter et al., 2008; Talbot et al., 2011).

\subsection{Quality assurance and quality control}

To maintain high standard measurements, the Tekran ${ }^{\circledR}$ instrument was calibrated every $25 \mathrm{~h}$ using the internal calibration source and these calibrations were checked against manual injections of known quantities of $\mathrm{Hg}^{0}$ before and after the cruises. The relative percent difference between manual injections and automated calibrations was less than $5 \%$ and the analytical precision was $<3 \%(n=6)$. To diminish the contamination from domestic waste and exhaust plume of the ship, we installed the Tekran ${ }^{\circledR}$ system inside the ship laboratory and mounted the sampling inlet at the front deck $2 \mathrm{~m}$ above the top deck using an unheated Teflon tube. The use of this Teflon tube might result in some adsorption of $\mathrm{Hg}^{\mathrm{P}}$ and RGM to the Teflon tubing. This system was designed to capture only the GEM since $\mathrm{Hg}^{\mathrm{P}}$ would be lost on the Teflon filter and the long unheated Teflon tube, and most of the RGM would be removed when passing the sampling tube, which was probably coated by sea salt during the sampling (Fu et al., 2010). Furthermore, the GEM was reported at a level at least 2 orders of magnitude higher than RGM in the MBL (Chand et al., 2008; Soerensen et al., 2010; Wang et al., 2016). Therefore, the atmospheric Hg measured using the Tekran ${ }^{\circledR}$ was referred to as GEM (Fu et al., 2010; Radke et al., 2007).

Before sampling, the $\mathrm{KCl}$ coated denuders and $\mathrm{Hg}^{\mathrm{P}}$ quartz filters were pre-cleaned by pyrolysis at $500{ }^{\circ} \mathrm{C}$ for $1 \mathrm{~h}$ and $900{ }^{\circ} \mathrm{C}$ for $3 \mathrm{~h}$ respectively to obtain low operational blanks. Quality assurance and quality control for $\mathrm{Hg}^{\mathrm{P}} 2.5$ and RGM were conducted using duplicates and field blanks. The mean relative differences of duplicated $\operatorname{Hg}_{2.5}{ }_{2.5}$ and $R G M$ samples $(n=6)$ were $15 \pm 9 \%$ and $17 \pm 10 \%$, respectively. The average field blank of denuders was $1.2 \pm 0.6 \mathrm{pg}$ $(n=6)$. The field blank filters were treated similarly to the other samples but not sampling. Routine maintenance practices (e.g. filter changes) were completed using particle free gloves and Teflon coated tweezers to reduce the possibility of contamination. Recent work has shown that heating of the inlet to $100{ }^{\circ} \mathrm{C}$ improves RGM collection (Huang and Gustin, 2015), and the $\mathrm{KCl}$ denuder oxidized $\mathrm{Hg}$ collection method may not be as robust as previously thought (Lyman et al., 2010). Although the $\mathrm{KCl}$-coated denuder method has yet to be improved (Gustin et al., 2015; Huang and Gustin, 2015), this method has become a standard method for measurement of RGM and has been widely used to measure RGM (Chand et al., 2008; Cheng et al., 2013a,b, 2014; Fu et al., 2011, 2012; Holmes et al., 2009; Kim et al., 2009; Liu et al., 2011; Mao and Talbot, 2012; Mao et al., 2012; Xu et al., 2015).

\section{Results and discussion}

\subsection{Speciated atmospheric $\mathrm{Hg}$ concentrations in the $\mathrm{MBL}$}

Fig. 3 shows the time series of GEM, RGM, $\mathrm{Hg}^{\mathrm{P}} 2.5$, and several meteorological parameters (e.g., $\mathrm{RH}$, air temperature, and wind speed) during the spring and fall cruises of 2014. The mean GEM concentration during spring $\left(2.03 \pm 0.72 \mathrm{ng} \mathrm{m}^{-3}, \mathrm{n}=5243\right)$ was comparable to that during fall $\left(2.09 \pm 1.58 \mathrm{ng} \mathrm{m}^{-3}, \mathrm{n}=4413\right)$ ( $t$-test, $\mathrm{p}>0.05)$. The mean GEM level during the whole study period was $2.07 \pm 1.16 \mathrm{ng} \mathrm{m}^{-3}$, which was higher than those in some other open oceans (see Table 1), such as the Atlantic Ocean (Laurier and Mason, 2007; Soerensen et al., 2013), the equatorial Pacific Ocean (Soerensen et al., 2014), the Adriatic Sea (Sprovieri and Pirrone, 2008), and the Indian Ocean (Witt et al., 2010), even higher than those of rural coastal sites in Canada (Cheng et al., 2014), and was comparable to those of coastal sites, such as the Hedo Station (Chand et al., 2008) in Japan, and the Augusta basin (Bagnato et al.,
2013) in Italy, but lower than those reported in the northern South China Sea (Fu et al., 2010; Tseng et al., 2012).

The mean $\operatorname{Hg}_{2.5}^{\mathrm{P}}$ concentration during spring was $8.2 \pm 6.3 \mathrm{pg} \mathrm{m}^{-3}(\mathrm{n}=39)$ (Table 1$)$ with a range of $1.8-28.4 \mathrm{pg} \mathrm{m}^{-3}$ except the two samples measured at Jiaozhou Bay in Qingdao, Shandong Province, China (Fig. 2a and left panel of Fig. 3), while the mean $\mathrm{Hg}_{2.5}{ }_{2.5}$ concentration during fall was $8.3 \pm 6.9 \mathrm{pg} \mathrm{m}^{-3}(\mathrm{n}=32)$ (Table 1) with a range of $1.0-31.3 \mathrm{pg} \mathrm{m}^{-3}$ except the two samples measured at Jiaozhou Bay (Fig. 2b and right panel of Fig. 3). The results showed that the average $\mathrm{Hg}^{\mathrm{P}} 2.5$ concentration in spring was comparable to that in fall ( $t$-test, $\mathrm{p}>0.1)$. This trend was consistent with the results obtained for GEM. The average $\mathrm{Hg}^{\mathrm{P}}{ }_{2.5}$ concentration during the entire study period was $10.1 \mathrm{pg} \mathrm{m}^{-3}(\mathrm{n}=75)$, which was higher than those of other oceanic, coastal, and even rural environments (see Table 1), such as the Adriatic Sea (Sprovieri and Pirrone, 2008), the Ontario Lake (Cheng et al., 2012), the Okinawa Island in Japan (Chand et al., 2008), the CPO (Weiss-Penzias et al., 2003) and the Weeks Bay (Engle et al., 2008) in the US, but obviously lower than the average $\mathrm{Hg}^{\mathrm{P}}{ }_{10}$ concentration $\left(15.6 \mathrm{pg} \mathrm{m}^{-3}\right)$ in the East Asia MBL (including the BS, YS, and East China Sea) (Wang et al., 2016), and considerably lower than those of Chinese rural sites, such as Waliguan (Fu et al., 2012) and Mt. Changbai (Wan et al., 2009).

The mean RGM concentration in spring $\left(2.5 \pm 1.7 \mathrm{pg} \mathrm{m}^{-3}\right.$ with a range of $0.2-9.8 \mathrm{pg} \mathrm{m}^{-3}, \mathrm{n}=60$ ) was significantly lower than that in fall $\left(4.3 \pm 2.5 \mathrm{pg} \mathrm{m}^{-3}\right.$ with a range of $\left.0.8-15.3 \mathrm{pg} \mathrm{m}^{-3}, \mathrm{n}=50\right)(t-$ test, $\mathrm{p}<0.01)$. The mean concentration of RGM during the entire study period was $3.3 \pm 2.3 \mathrm{pg} \mathrm{m}^{-3}(\mathrm{n}=110)$, which was comparable to the global mean concentration of RGM in the MBL (Soerensen et al., 2010), and somewhat higher than those of rural or coastal areas in North America (Table 1), such as the Ontario Lake (Cheng et al., 2012), several coastal sites in Nova Scotia (Cheng et al., 2013a, 2014), and slightly lower than those of other seas, such as the Mediterranean Sea (Sprovieri et al., 2003), the Weeks Bay (Engle et al., 2008), the Adriatic Sea (Sprovieri and Pirrone, 2008), the subtropical North Atlantic (Laurier and Mason, 2007), the Okinawa Island (Chand et al., 2008), and the North Pacific Ocean (Laurier et al., 2003). But RGM concentrations measured in this study area were much lower than those of urban or rural sites in China and South Korea, such as Guiyang (Fu et al., 2011; Liu et al., 2011), Xiamen (Xu et al., 2015), Mt. Changbai (Wan et al., 2009), and Seoul (Kim et al., 2009).

Overall, the higher concentrations and larger variability of GEM and $\mathrm{Hg}_{2.5}{ }_{2.5}$ over the BS compared to over the YS (Fig. 3) demonstrated that the BS was influenced by human activities more seriously than the YS. Moreover, the long-lived GEM showed smaller variability (especially over the YS) compared to the short-lived species like RGM and $\operatorname{Hg}^{\mathrm{P}} 2.5$, indicating that the RGM and $\operatorname{Hg}^{\mathrm{P}} 2.5$ were easily removed from the marine atmosphere because of their higher activity and solubility. Interestingly, it could be found that the average value of reactive $\mathrm{Hg}\left(\mathrm{RGM}+\mathrm{Hg}^{\mathrm{P}}{ }_{2.5}\right.$ ) (Rutter and Schauer, 2007) in spring was comparable to that in fall, and the reactive $\mathrm{Hg}$ constitutes less than $1 \%$ of TAM in the $\mathrm{MBL}$, which was comparable to those observed in other remote sites, such as the two sites in the Bay St. François wetlands (Poissant et al., 2004), and the Okinawa Island (Chand et al., 2008). The results suggested that most $\mathrm{Hg}$ export in the BS and YS was GEM and the direct anthropogenic emission of reactive $\mathrm{Hg}$ was very small.

\subsection{Spatial distributions of atmospheric $\mathrm{Hg}$ in the $\mathrm{MBL}$}

The spatial distributions of GEM during the spring and fall cruises can be found in our previous study (Wang et al., 2016). The spatial distributions of $\operatorname{Hg}^{\mathrm{P}} 2.5$ in the MBL of the BS and YS were illustrated in Fig. 4a and b. During spring, two higher $\operatorname{Hg}_{2.5}^{\mathrm{P}}$ 


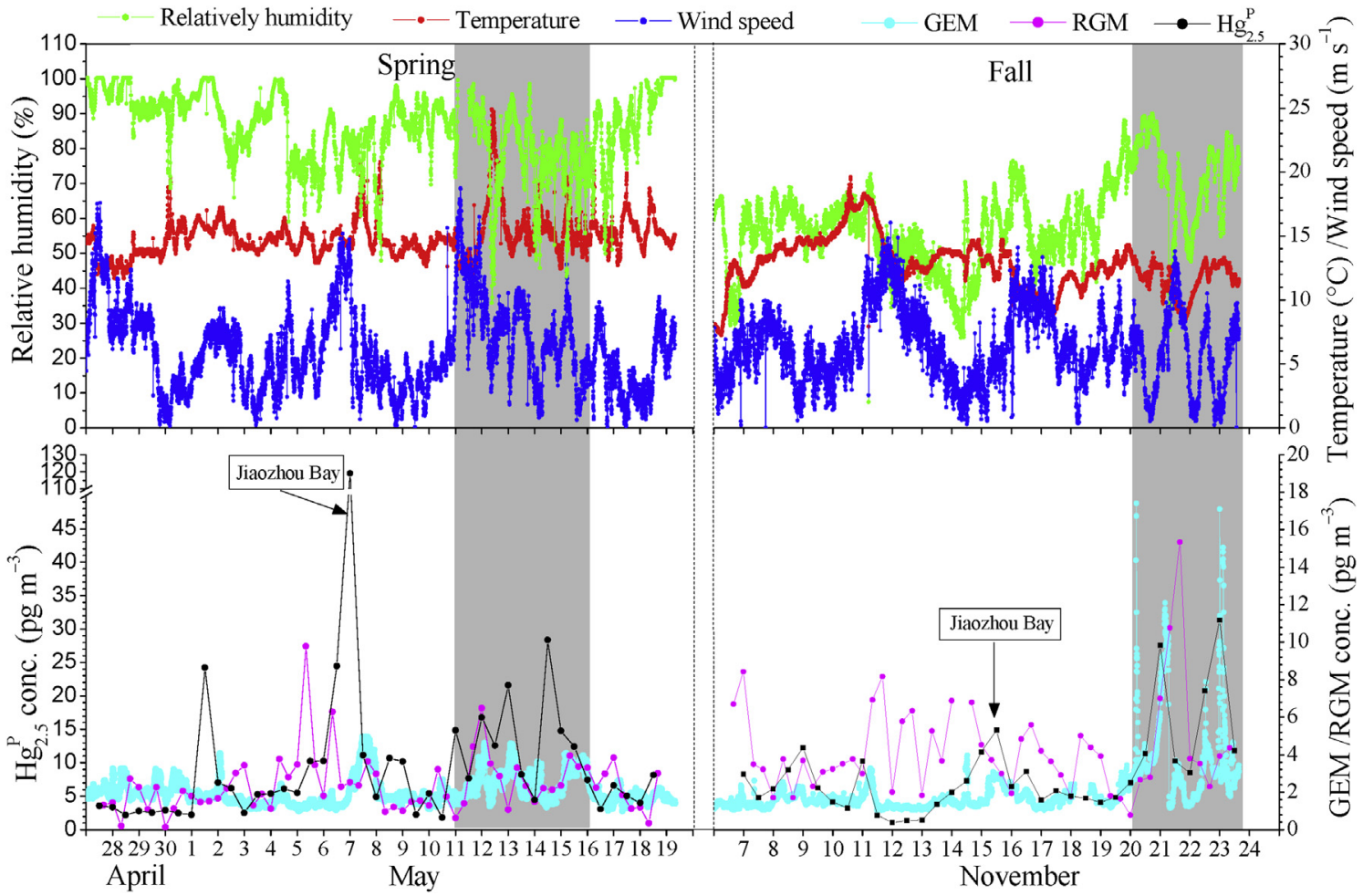

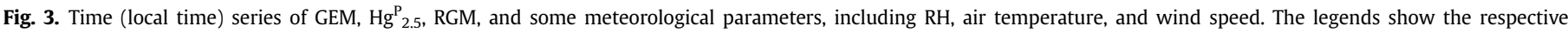
variables, the light gray areas represent the samples in the BS.

Table 1.

The GEM, $\mathrm{Hg}^{\mathrm{P}}{ }_{2.5}$, and RGM concentrations in this study and values reported in other literature.

\begin{tabular}{|c|c|c|c|c|c|c|c|}
\hline \multicolumn{2}{|c|}{ Location } & \multirow{2}{*}{$\begin{array}{l}\text { Classification } \\
\text { Sea }\end{array}$} & \multirow{2}{*}{$\frac{\text { Sampling time }}{2014 \text { (Spring) }}$} & \multirow{2}{*}{$\begin{array}{l}\text { GEM }\left(\mathrm{ng} \mathrm{m}^{-3}\right) \\
2.03 \pm 0.72\end{array}$} & \multirow{2}{*}{$\begin{array}{l}\mathrm{Hg}_{2.5}^{\mathrm{P}}\left(\mathrm{pg} \mathrm{m}^{-3}\right) \\
11.3 \pm 18.5\end{array}$} & \multirow{2}{*}{$\frac{\mathrm{RGM}\left(\mathrm{pg} \mathrm{m}^{-3}\right)}{2.5 \pm 1.7}$} & \multirow{2}{*}{$\begin{array}{l}\text { Reference } \\
\text { This study }\end{array}$} \\
\hline China & BS and YS & & & & & & \\
\hline & BS and YS & Sea & 2014 (Fall) & $2.09 \pm 1.58$ & $9.0 \pm 9.0$ & $4.3 \pm 2.5$ & This study \\
\hline & Mt. Changbai & Remote & $2005-2006$ & $3.58 \pm 1.78$ & $77 \pm 136$ & $65 \pm 84$ & Wan et al., 2009 \\
\hline & Waliguan & Remote & $2007-2008$ & $1.98 \pm 0.98$ & $19.4 \pm 18.1$ & $7.4 \pm 4.8$ & Fu et al., 2012 \\
\hline \multirow[t]{2}{*}{ USA } & $\mathrm{CPO}^{\mathrm{a}}$ & Coastal & $2001-2002$ & 1.55 & 0.5 & $<1.6$ & Weiss-Penzias et al., 2003 \\
\hline & Weeks Bay & Coastal & $2005-2006$ & $1.6 \pm 0.3$ & $2.7 \pm 3.4$ & $4.0 \pm 7.5$ & Engle et al., 2008 \\
\hline \multirow[t]{4}{*}{ Canada } & Ontario Lake & Remote & $2005-2006$ & $1.57 \pm 0.22$ & $4.42 \pm 3.67$ & $0.99 \pm 1.89$ & Cheng et al., 2012 \\
\hline & Nova Scotia & Coastal & $2010-2011$ & $1.67 \pm 1.01$ & $2.32 \pm 3.09$ & $2.07 \pm 3.35$ & Cheng et al., 2013a \\
\hline & Nova Scotia & Coastal-rural & $2010-2011$ & $1.38 \pm 0.20$ & $3.5 \pm 4.5$ & $0.4 \pm 1.0$ & Cheng et al., 2014 \\
\hline & Nova Scotia & Coastal-urban & $2010-2011$ & $1.67 \pm 1.01$ & $2.3 \pm 3.1$ & $2.1 \pm 3.4$ & Cheng et al., 2014 \\
\hline Korea & Seoul & Urban & $2005-2006$ & $3.22 \pm 2.10$ & $23.9 \pm 19.6$ & $27.2 \pm 19.3$ & Kim et al., 2009 \\
\hline Japan & Okinawa Island & Coastal-rural & 2004 & $2.04 \pm 0.38$ & $3.0 \pm 2.5$ & $4.5 \pm 5.4$ & Chand et al., 2008 \\
\hline \multicolumn{2}{|c|}{ North Atlantic Ocean } & Ocean & 2003 & $1.63 \pm 0.08$ & $N A^{b-2 a}$ & $5.9 \pm 4.9$ & Laurier and Mason, 2007 \\
\hline \multicolumn{2}{|c|}{ North Pacific Ocean } & Ocean & 2002 & 2.5 & NA & 9.5 & Laurier et al., 2003 \\
\hline \multicolumn{2}{|c|}{ Mediterranean Sea } & Ocean & 2000 & $1.9 \pm 1.0$ & NA & 7.9 & Sprovieri et al., 2003 \\
\hline \multicolumn{2}{|c|}{ Global Ocean } & Ocean & $2006-2007$ & $1.53 \pm 0.58$ & NA & $3.1 \pm 11.0$ & Soerensen et al., 2010 \\
\hline \multicolumn{2}{|c|}{ Adriatic Sea } & Ocean & 2004 & $1.6 \pm 0.4$ & $4.5 \pm 8.0$ & $6.7 \pm 11.7$ & Sprovieri and Pirrone, 2008 \\
\hline
\end{tabular}

a CPO: Cheeka Peak Observatory.

b NA: no data available.

concentrations ( 119.0 and $24.5 \mathrm{pg} \mathrm{m}^{-3}$ ) were observed at Jiaozhou Bay during the daytime and nighttime on the day of 7 May 2014 presumably because of the local human activities, while the lowest $\mathrm{Hg}^{\mathrm{P}}{ }_{2.5}$ concentration (1.8 $\mathrm{pg} \mathrm{m}^{-3}$ ) was observed in the northern YS during daytime on the day of 11 May 2014 (Fig. 4a). During fall, the maximum and minimum values of $\mathrm{Hg}^{\mathrm{P}} 2.5$ concentrations were observed in the BS and southern YS respectively (Fig. 4b). Fig. 4a and $\mathrm{b}$ show that the spatial distributions of $\mathrm{Hg}^{\mathrm{P}}{ }_{2.5}$ generally reflected a gradient with high levels near the coast of East China and low levels in the open sea both in spring and fall, suggesting significant atmospheric $\operatorname{Hg}_{2.5}$ outflow from China. Interestingly, higher $\mathrm{Hg}^{\mathrm{P}} 2.5$ concentrations generally went with the higher GEM concentrations during the two cruises (especially over the BS), which could be found in Fig. $4 \mathrm{a}$ and $\mathrm{b}$ in this study and Fig. 2 in our previous study (Wang et al., 2016). This was probably due to the large anthropogenic $\mathrm{Hg}$ (including the GEM and $\mathrm{Hg}^{\mathrm{P}}$ ) emissions in China (Zhang et al., 2015).

However, there was large difference in $\mathrm{Hg}^{\mathrm{P}} 2.5$ concentration between the BS and YS. The average $\mathrm{Hg}^{\mathrm{P}} 2.5$ concentrations in the BS (spring: $15.5 \mathrm{pg} \mathrm{m}^{-3}$, fall: $16.7 \mathrm{pg} \mathrm{m}^{-3}$ ) were more than 2 times higher than those in the YS (spring: $6.7 \mathrm{pg} \mathrm{m}^{-3}$, fall: $7.0 \mathrm{pg} \mathrm{m}^{-3}$ ) both in spring (Fig. 4a) and fall (Fig. 4b). We speculate that the 

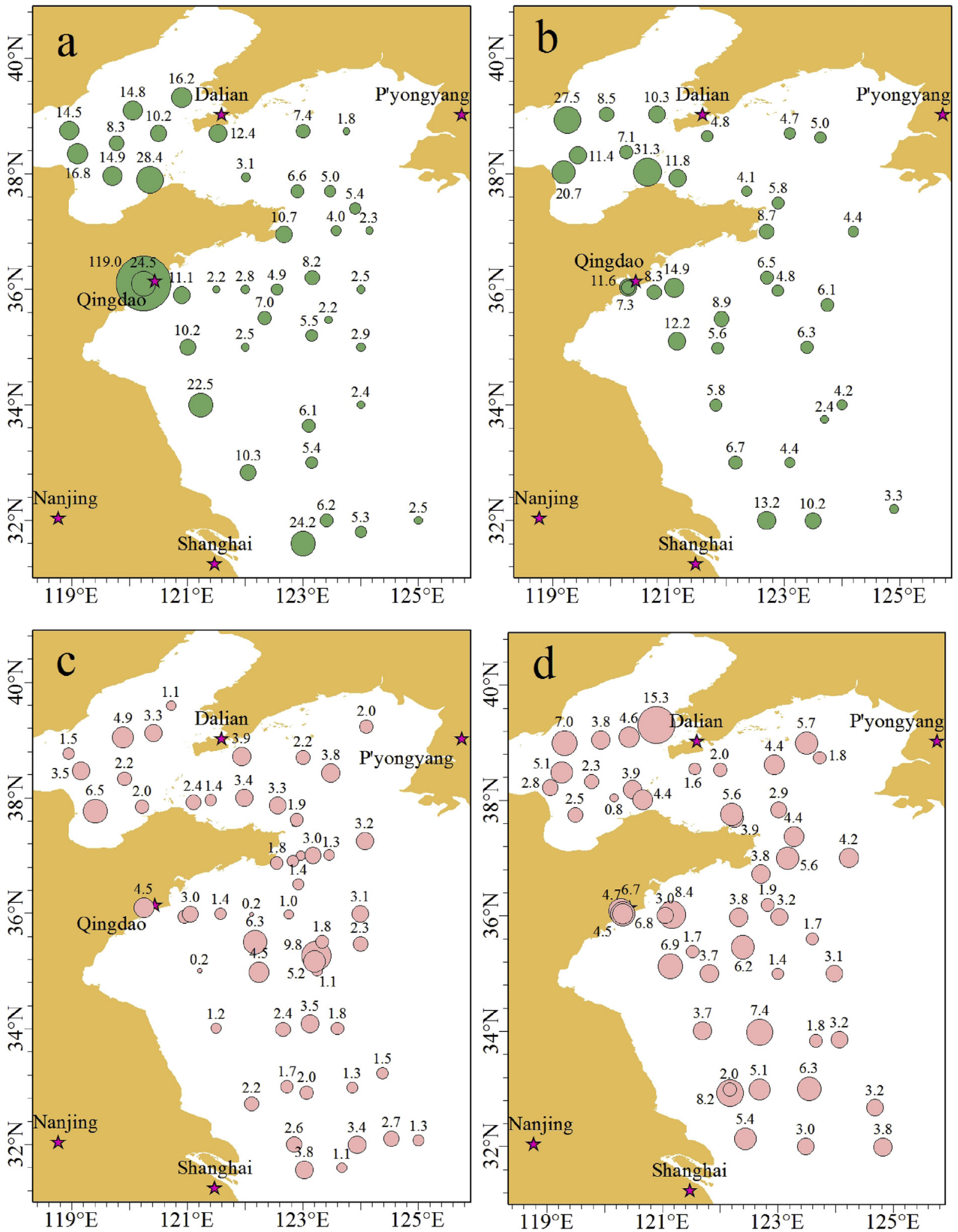

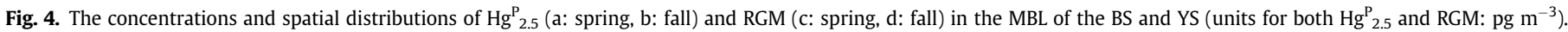

$\mathrm{Hg}^{\mathrm{P}} 2.5$ in the BS mainly originated from the surrounding land areas due to the large emission of $\mathrm{Hg}^{\mathrm{P}}$. The $\mathrm{BS}$ was more susceptible to the anthropogenic pollutants than the YS due to its specific location. Additionally, it could be found that the $\mathrm{Hg}^{\mathrm{P}}{ }_{2.5}$ concentrations in the BS were comparable to those observed in Jiaozhou Bay, and $\mathrm{Hg}^{\mathrm{P}} 2.5$ concentrations varied more markedly on the diel time scale in the BS compared to those in the YS (Fig. 4a and b), which further indicated that $\mathrm{Hg}^{\mathrm{P}}{ }_{2.5}$ in the BS was dramatically influenced by any local (e.g., marine oil exploration) or regional processes.

The spatial distributions of RGM over the BS and YS were plotted 
in Fig. 4c and d. RGM showed homogeneous distributions over the study area both in spring and fall. The lower concentrations and homogeneous distributions of RGM indicated that the majority of the RGM presumably not originated from the land. Interestingly, the RGM concentrations during fall were generally higher than those during spring (see Fig. 4c and d), which maybe due to the difference in RH between spring and fall (RGM has strong water solubility and activity), and the detailed discussions can be found in the next section. In addition, there was no significant difference in RGM concentrations between the BS (spring: $3.1 \mathrm{pg} \mathrm{m}^{-3}$, fall: $4.8 \mathrm{pg} \mathrm{m}^{-3}$ ) and YS (spring: $2.6 \mathrm{pg} \mathrm{m}^{-3}$, fall: $4.1 \mathrm{pg} \mathrm{m}^{-3}$ ) both in spring ( $t$-test, $\mathrm{p}>0.05$ ) and fall ( $t$-test, $\mathrm{p}>0.05$ ).

\subsection{Diurnal variation of speciated atmospheric $\mathrm{Hg}$ and the potential sources of RGM in the MBL}

\subsubsection{Diurnal variation of GEM in the $M B L$}

The diurnal variation of GEM concentrations during the spring and fall cruises was illustrated in Fig. 5. The amplitude (difference between maxima and minima) of diurnal variation of GEM in the BS was much greater than that in the YS both in spring and fall. Actually, as shown in Fig. 1, the BS is surrounded by numerous industrial provinces, and the large emissions of $\mathrm{Hg}$ from China have seriously impacted the GEM distribution in the BS. The GEM concentrations over the BS dominantly fell in the range of 2.0-4.0 $\mathrm{ng} \mathrm{m}^{-3}$ (Fig. 5a and b), while they mainly fell in the range of $1.5-2.0 \mathrm{ng} \mathrm{m}^{-3}$ over the YS (Fig. $5 \mathrm{c}$ and $\mathrm{d}$ ). It could be found that GEM concentrations in spring were generally higher than those in fall in the YS (Fig. 5c and d), which was in contrast to the GEM results obtained in the BS (Fig. 5a and b). In the BS, GEM concentrations in the daytime were higher than those in the nighttime during spring (Fig. 5a), while opposite result was observed during fall, just as illustrated in Fig. 5b, GEM suddenly decreased at 01:00 and then suddenly increased at 19:00 in fall, which demonstrated that the BS was seriously polluted by $\mathrm{Hg}$ pollutant. It was notable that there was no consistent diurnal pattern of GEM over the BS (Fig. 5a and b) presumably due to the significantly influence of human activities. In the YS, the mean GEM concentration in the daytime was significantly lower than that in the nighttime during spring ( $t$-test, $\mathrm{p}<0.01$ ) (Fig. $5 \mathrm{c}$ ). One probable reason was the oxidation of GEM in the daytime (Lindberg et al., 2002). Although the mean GEM concentration in the nighttime was comparable to that in the daytime, the GEM levels slowly decreased in the daytime during fall (especially after 10 a.m.) (Fig. 5d). The smaller variability and lower concentrations of GEM over the YS indicated that the YS suffered less influence of human activities. According to the previous study conducted in 2012, the GEM levels during the two cruises in the YS were similar (spring: $1.86 \pm 0.40 \mathrm{ng} \mathrm{m}^{-3}$, fall: $1.84 \pm 0.50 \mathrm{ng} \mathrm{m}^{-3}$ ) (Ci et al., 2015), which were comparable to those of our observations in the YS.

\subsubsection{Diurnal variation of $\mathrm{Hg}^{P} 2.5$ and RGM in the MBL}

Fig. 6a shows the $\mathrm{Hg}^{\mathrm{P}} 2.5$ concentrations in the daytime and nighttime during the entire study period. During spring, the mean $\mathrm{Hg}^{\mathrm{P}} 2.5$ concentration in the nighttime $\left(9.0 \pm 5.2 \mathrm{pg} \mathrm{m}^{-3}, \mathrm{n}=19\right)$ was slightly higher than that in the daytime $\left(7.1 \pm 5.9 \mathrm{pg} \mathrm{m}^{-3}, \mathrm{n}=20\right)$ except the two samples in the Jiaozhou Bay. Similarly, during the fall cruise, the mean $\operatorname{Hg}_{2.5}$ concentration in the nighttime $\left(10.3 \pm 8.3 \mathrm{pg} \mathrm{m}^{-3}\right)$ was also somewhat higher than that in the daytime $\left(6.6 \pm 4.7 \mathrm{pg} \mathrm{m}^{-3}\right)$. But in fact, with exception of the samples observed in the Jiaozhou Bay and BS, there was no significant difference in $\mathrm{Hg}^{\mathrm{P}}{ }_{2.5}$ concentrations between day and night in the YS both in spring and fall (Fig. 6a), which was consistent with the GEM results in the YS (Fig. 5d). The results suggested that the YS
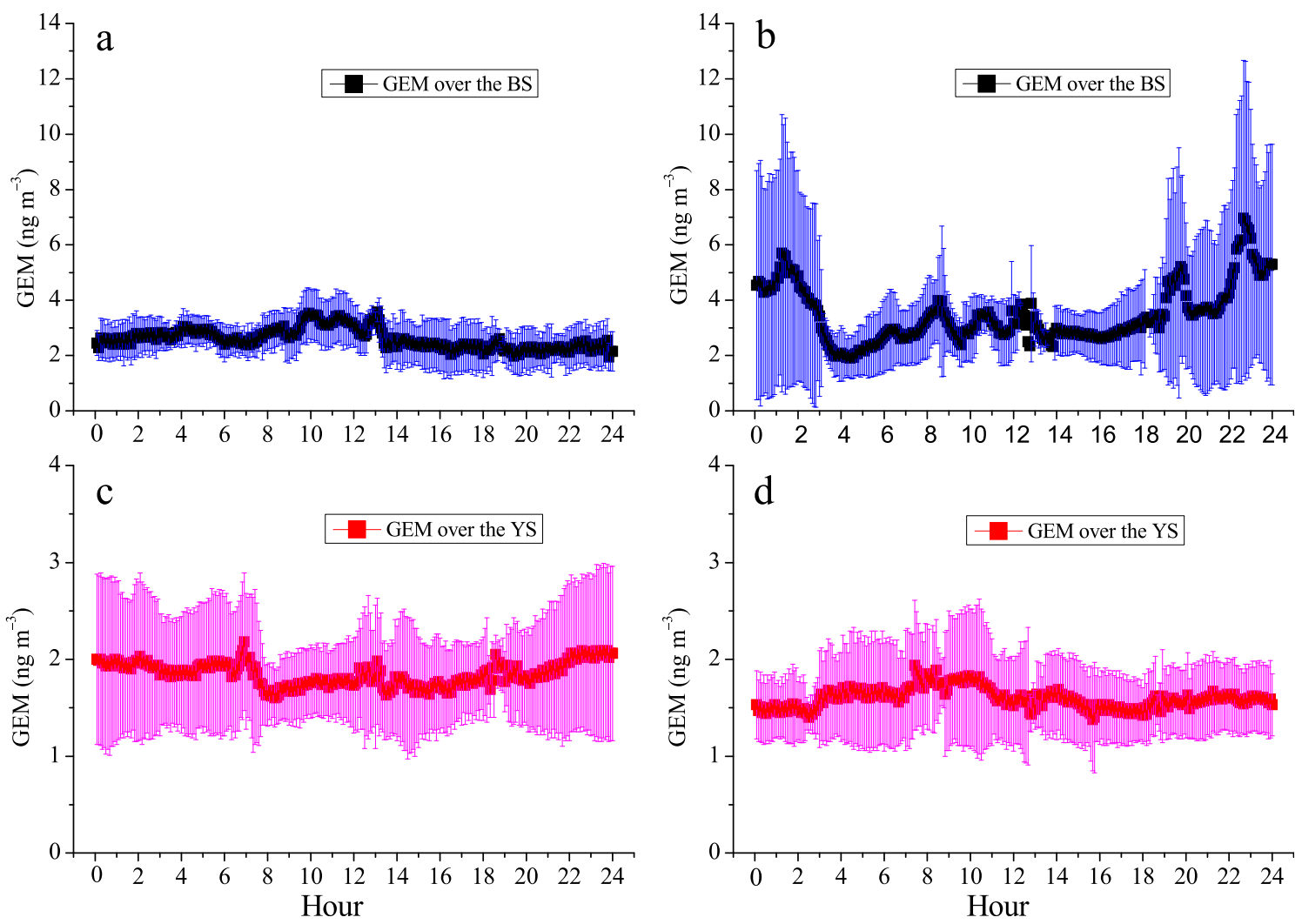

Fig. 5. Diurnal variation of atmospheric GEM concentrations (mean \pm SD) over the BS (a: spring, b: fall) and YS (c: spring, d: fall). 

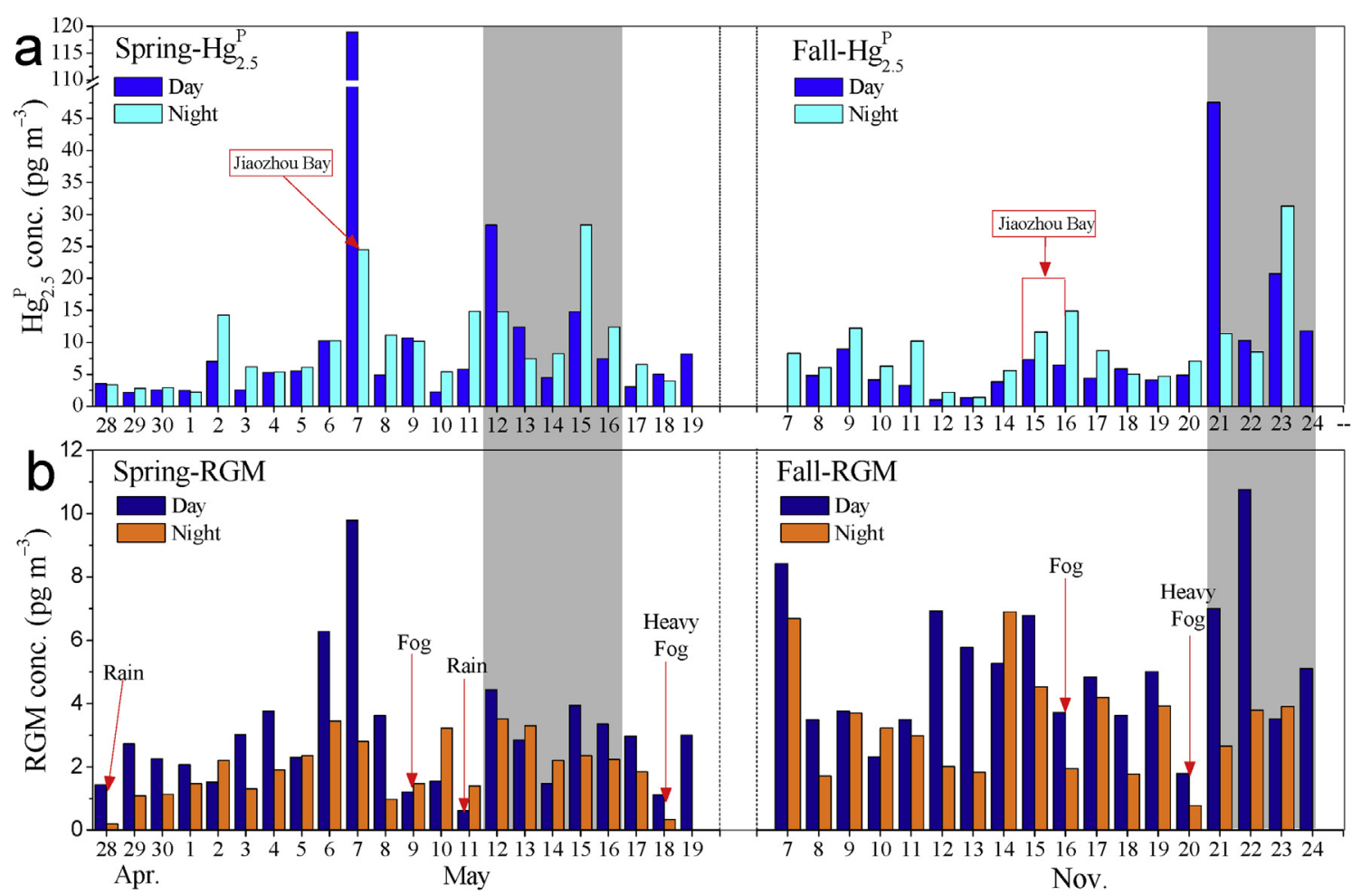

Fig. 6. $\mathrm{Hg}_{2.5}^{\mathrm{P}}$ (a) and RGM (b) concentrations in the daytime and nighttime during the spring and fall cruises, the light gray areas represent the samples in the BS.

suffered less anthropogenic $\mathrm{Hg}^{\mathrm{P}}$ as compared to the BS and the $\mathrm{Hg}^{\mathrm{P}}{ }_{2.5}$ over the YS presumably originated from both the in-situ formation and anthropogenic emissions.

The time series of RGM concentrations in the daytime and nighttime were plotted in Fig. 6b. Generally, RGM showed a diurnal variation with higher levels in the daytime and lower levels in the nighttime during the entire study period. During spring, the average RGM concentration in the daytime $\left(3.2 \pm 1.9 \mathrm{pg} \mathrm{m}^{-3}\right)$ was significantly higher than that in the nighttime $\left(1.8 \pm 0.9 \mathrm{pg} \mathrm{m}^{-3}\right)(t-$ test, $\mathrm{p}<0.01$ ). We found a similar pattern during fall, and the mean RGM concentration in the daytime $\left(5.0 \pm 2.3 \mathrm{pg} \mathrm{m}^{-3}\right)$ was also significantly higher than that in the nighttime $\left(3.4 \pm 1.8 \mathrm{pg} \mathrm{m}^{-3}\right)(t-$ test, $\mathrm{p}<0.05$ ). Our results were consistent with the previous multiple-sites (e.g., coastal, oceanic, and urban sites) studies (Cheng et al., 2014; Engle et al., 2008; Laurier and Mason, 2007; Liu et al., 2007), which showed that the RGM typically followed a diurnal pattern with lower concentrations in the nighttime and higher concentrations in the daytime. Numerous field studies have shown that GEM in the MBL can be rapidly oxidized to form RGM in-situ (Chand et al., 2008; Hedgecock and Pirrone, 2001; Hedgecock et al., 2003; Laurier et al., 2003; Laurier and Mason, 2007; Soerensen et al., 2010; Sprovieri et al., 2003, 2010). In addition, the oxidation of GEM must be photochemical, as evidenced by the observed seasonal cycle of GEM (Selin et al., 2007) and the diurnal cycle of RGM (Laurier and Mason, 2007). For these reasons, we attribute the diurnal variation of RGM to the photochemical activity. We speculate that there are at least three main reasons for the lower RGM concentrations in the nighttime: (a) there is no solar radiation at night, and there is little RGM production; (b) the higher $\mathrm{RH}$ during nighttime is conductive to the removal of RGM; and (c) the lower air temperature during nighttime is beneficial to the partitioning of RGM from the gas to the particle phase (Amos et al., 2012; Rutter and Schauer, 2007), while more further studies are needed to verify these hypotheses.
Fig. 6b shows that there was large difference in RGM concentration between the beginnings of the two cruises. The RGM concentrations in the beginning of the spring cruise were far lower than those in the beginning of the fall cruise. According to our observations on the weather conditions, it was a rainy day on 28 April 2014, when the $\mathrm{RH}$ reached $100 \%$ and the wind speed was very high $\left(>12 \mathrm{~m} \mathrm{~s}^{-1}\right)$ (see Fig. 3 ). The lower concentrations of $\mathrm{Hg}^{\mathrm{P}}{ }_{2.5}$ and $\mathrm{RGM}$ (Fig. $6 \mathrm{a}$ and $\mathrm{b}$ ) in the first day of the spring sampling time might be caused by wet scavenging since the first sampling day experienced precipitation, while it was a sunny day on 7 November 2014 with lower RH (40-50\%) and wind speed (< $7 \mathrm{~m} \mathrm{~s}^{-1}$ ) (see Fig. 3). Moreover, it was obviously found that the RGM and $\mathrm{Hg}^{\mathrm{P}} 2.5$ concentrations were considerably lower in the rainy and heavy foggy weather than those in the fine days (e.g., 2-4 May 2014 and 7-10 November 2014) (see Fig. 6a and b), while we found lower RGM and relatively higher $\operatorname{Hg}^{\mathrm{P}}{ }_{2.5}$ concentrations during the period of little fog. Therefore, we suggest that the solar radiation and $\mathrm{RH}$ have significant influence on the formation and removal of RGM in the MBL (Selin et al., 2007; Laurier and Mason, 2007; Soerensen et al., 2010)

\subsubsection{Potential sources of RGM in the $M B L$}

Previous studies suggested that RGM production is believed to primarily occur via ozone $\left(\mathrm{O}_{3}\right)$ and hydroxyl radical $(\mathrm{OH})$ oxidation of $\mathrm{Hg}^{0}$ (Calvert and Lindberg, 2005; Pal and Ariya, 2004a,b). Recently, both experimental and theoretical studies suggested that the gas phase recombination of $\mathrm{Hg}^{0}$ with halogen atoms is sufficiently fast to initiate the oxidation process of $\mathrm{Hg}^{0}$ (AuzmendiMurua et al., 2014; Wang et al., 2015), and the oxidation of $\mathrm{Hg}^{0}$ must be photochemical (Laurier and Mason, 2007; Selin et al., 2007). Numerous studies have suggested that reactive halogen species ( $\mathrm{Br}, \mathrm{Cl}$, and $\mathrm{BrO}$ etc.) that generated from sea salt aerosols (Sander et al., 2003; Sheu and Mason, 2004; Soerensen et al., 2010) may be the dominant sources for the oxidation of $\mathrm{Hg}^{0}$ in the MBL 
(Auzmendi-Murua et al., 2014; Holmes et al., 2010; Laurier et al., 2003; Seigneur and Lohman, 2008; Steffen et al., 2015), while this process may be limited in coastal environments because of the higher $\mathrm{O}_{3}$ concentration (Laurier and Mason, 2007; Lyman et al., 2010). Holmes et al. (2009, 2010) studied the sources of RGM in the marine atmosphere, and they suggested that $80-95 \%$ of divalent $\mathrm{Hg}\left(\mathrm{Hg}^{\mathrm{II}}\right)$ in the MBL was present in sea salt aerosols rather than gas-phase and the RGM was mainly from the oxidation of $\mathrm{Hg}^{0}$ by $\mathrm{Br}$ and $\mathrm{O}_{3}$. A recent study suggested that up to $100 \%$ conversion of GEM to RGM has been observed in the Arctic (Steffen et al., 2015).

It is now generally accepted, even though not fully understood, that $\mathrm{Hg}^{0}$ oxidation and $\mathrm{RGM}$ production are closely related to photochemically induced heterogeneous and autocatalytic reactions involving sea-salt particles and reactive halogen species (Lindberg et al., 2002). The reactions with atomic $\mathrm{Br}$ and $\mathrm{Cl}$ have substantially larger rate constants (Ariya et al., 2002; Ariya and Ryzhkov, 2003; Wang et al., 2015) and therefore oxidation by these mechanisms may proceed faster than oxidation by $\mathrm{O}_{3}$ and $\mathrm{OH}$ even though the concentrations of the halogen radicals in the MBL were substantially lower than that of $\mathrm{O}_{3}$. However, the results of spatial distributions of RGM (Fig. 4c and d) showed that higher RGM levels were often observed in the offshore areas, and the RGM concentrations in the BS were slightly higher than those in the YS, which indicated that a small portion of RGM presumably originated from the surrounding land or offshore oil exploitation (e.g., in the BS). Therefore, in this study, we speculate that the RGM in the open sea was mainly from the oxidation of $\mathrm{Hg}^{0}$ by reactive halogen species, while the RGM in coastal environments was predominately from both the oxidation of $\mathrm{Hg}^{0}$ and anthropogenic emissions. In addition, a little part of RGM probably originated from the free troposphere (Weiss-Penzias et al., 2009; Wang et al., 2015).

\subsection{Relationships between speciated atmospheric $\mathrm{Hg}$ and meteorological parameters}

The descriptive statistics for correlation coefficients for speciated atmospheric $\mathrm{Hg}$ and meteorological parameters during the two sampling campaigns were summarized in Table 2 . The elevated GEM concentrations and the strong positive relationship between $\mathrm{Hg}^{\mathrm{P}} 2.5$ and GEM (Pearson's correlation coefficient) both in spring and fall suggested that the $\mathrm{Hg}^{\mathrm{P}}$ 2.5 likely originated from the land, while the $\mathrm{Hg}^{\mathrm{P}} 2.5$ had no significant correlation with $\mathrm{RH}$ and air temperature (Table 2). There was no significant correlation between RGM and GEM during the whole study period, while significantly positive correlation between RGM and air temperature was found both in spring and fall (Table 2). One of the reasons could be related to an increase in atmospheric radical production (especially during daytime) and subsequent formation of RGM (Mao and Talbot, 2012; Mao et al., 2012). Besides, the higher air temperature was conductive to partitioning of RGM from the particle phase to the gaseous phase, and this trend has been demonstrated in the previous studies (Choi et al., 2008; Rutter and Schauer, 2007). Moreover, the correlations of RGM-wind speed and $\mathrm{Hg}^{\mathrm{P}} 2.5$-wind speed were not significant both in spring and fall (Table 2), which were consistent with the previous study conducted at two coastal sites (Cheng et al., 2014). Furthermore, a significantly negative correlation was observed between RGM and RH during the fall cruise (see Table 2), which demonstrated that elevated $\mathrm{RH}$ may facilitate the removal of RGM. However, the RGM-RH correlation was not significant during spring probably due to the much higher $\mathrm{RH}$ (generally $>80 \%$ ). Our findings (negative correlation between RGM and RH, positive correlation between RGM and air temperature) were consistent with the previous studies conducted at the coastal and marine locations (Cheng et al., 2014; Mao et al., 2012). More efforts and research work are needed to account for such phenomenon. Cheng et al. (2014) had proposed two potential factors for the strong negative correlation between RGM and RH: (1) higher humidity increases particle growth and thus particle surface area which in turn increases partitioning of RGM to particles (by decreasing RGM); and (2) RGM positively correlates with air temperature while RH negatively correlates with air temperature under fixed water vapor content.

As show in Fig. 7, the RGM and $\operatorname{Hg}^{\mathrm{P}} 2.5$ predominately fell in the $\mathrm{RH}$ range of $70-100 \%$ during spring, while they dominantly fell in the range of $50-80 \%$ during fall. We found an interesting phenomenon that the higher the RH and the lower the RGM concentration both in spring and fall, but there was no distinct difference in $\mathrm{Hg}^{\mathrm{P}}{ }_{2.5}$ concentration between higher and lower RH. Additionally, there was no significant correlation between RGM and $\mathrm{Hg}^{\mathrm{P}} 2.5$ both in spring and fall (see Table 2 and Fig. 7) probably due to their higher activity and deposition rates. Priorities for future research include identification of $\mathrm{Hg}^{\mathrm{P}}$ and RGM compounds in ambient air and development of information on their chemical and physical properties (Gustin et al., 2015).

\section{Conclusions}

During the spring and fall cruises of 2014, speciated atmospheric $\mathrm{Hg}$ was determined in the MBL of the BS and YS downwind of the East Asia. Our observations of RGM and $\operatorname{Hg}^{\mathrm{P}}{ }_{2.5}$ represent the first reported measurements in the BS and YS. The average concentrations of GEM and $\mathrm{Hg}^{\mathrm{P}} 2.5$ in spring were comparable to those in fall, while RGM concentrations were generally higher in fall than in spring. Moreover, the $\mathrm{Hg}^{\mathrm{P}}{ }_{2.5}$ showed spatial distributions with higher concentrations in the offshore area and lower values in the open sea. The larger variability and higher concentrations of GEM, $\mathrm{Hg}^{\mathrm{P}}{ }_{2.5}$, and RGM concentrations in the BS as compared to those in the YS demonstrated that the BS was more vulnerable to anthropogenic $\mathrm{Hg}$. Our results suggested that reactive $\mathrm{Hg}\left(\mathrm{RGM}+\mathrm{Hg}^{\mathrm{P}}{ }_{2.5}\right)$ comprised $<1 \%$ of the TAM, indicating that most $\mathrm{Hg}$ export in the BS and YS was GEM. Inspection of the RGM and $\mathrm{Hg}^{\mathrm{P}} 2.5$ concentrations during daytime and nighttime, the RGM concentrations in the daytime were significantly higher than those in the nighttime during the entire study period, but opposite results for $\mathrm{Hg}^{\mathrm{P}}{ }_{2.5}$ were observed. Correlation analysis showed that there was a significantly positive correlation between $\mathrm{Hg}^{\mathrm{P}} 2.5$ and GEM during the entire

Table 2.

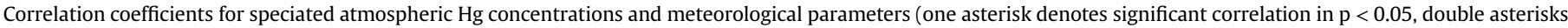
denotes significant correlation in $\mathrm{p}<0.01$ ).

\begin{tabular}{|c|c|c|c|c|c|c|c|c|c|c|c|}
\hline \multirow[t]{2}{*}{ Season } & \multirow[t]{2}{*}{ Speciation } & \multicolumn{2}{|l|}{ GEM } & \multicolumn{2}{|l|}{$\mathrm{Hg}^{\mathrm{P}}{ }_{2.5}$} & \multicolumn{2}{|c|}{ Temperature } & \multicolumn{2}{|l|}{$\mathrm{RH}$} & \multicolumn{2}{|c|}{ Wind speed } \\
\hline & & $\mathrm{p}$ & $r$ & $\mathrm{p}$ & $r$ & $\mathrm{p}$ & $r$ & $\mathrm{p}$ & $r$ & $\mathrm{p}$ & $\mathrm{r}$ \\
\hline \multirow[t]{2}{*}{ Spring } & RGM & 0.881 & -0.020 & \multirow[t]{2}{*}{0.774} & \multirow[t]{2}{*}{0.045} & 0.017 & $0.307^{*}$ & 0.443 & -0.101 & 0.556 & 0.077 \\
\hline & $\mathrm{Hg}^{\mathrm{P}}{ }_{2.5}$ & $<0.01$ & $0.635^{* *}$ & & & 0.182 & 0.208 & 0.873 & -0.025 & 0.772 & 0.045 \\
\hline \multirow[t]{2}{*}{ Fall } & RGM & 0.713 & -0.053 & \multirow[t]{2}{*}{0.225} & \multirow[t]{2}{*}{0.191} & 0.031 & $0.305^{*}$ & 0.014 & $-0.344^{*}$ & 0.055 & 0.274 \\
\hline & $\mathrm{Hg}_{2.5}^{\mathrm{P}}$ & $<0.01$ & $0.522^{* *}$ & & & 0.983 & -0.003 & 0.233 & 0.188 & 0.523 & 0.101 \\
\hline
\end{tabular}



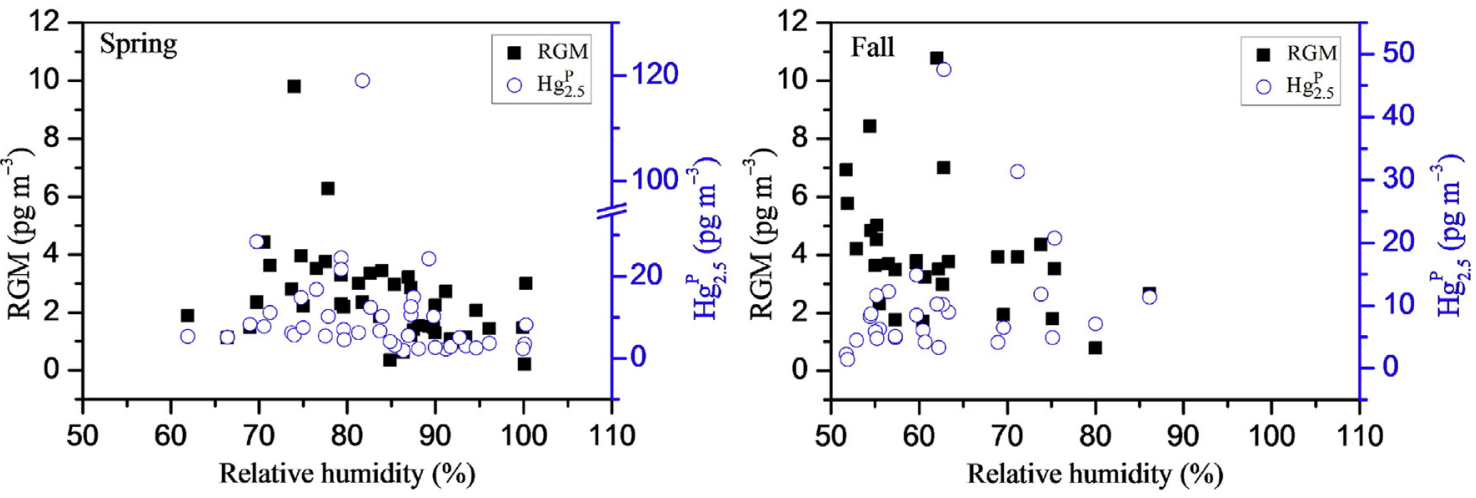

Fig. 7. Humidity compared with concentrations of RGM and $\mathrm{Hg}^{\mathrm{P}}{ }_{2.5}$.

study period, the RGM-air temperature correlation was positive and the RGM-RH correlation was negative during the entire study period. Overall, the human activities in East Asia (mainly China) have a significant influence on the oceanic $\mathrm{Hg}$ cycle in the BS and YS. However, from what is currently known about the atmospheric chemistry of $\mathrm{Hg}$ in the East Asian MBL, short-term measurements are insufficient to determine the chemical mechanisms occurring and the long-term measurements concurrent with wet and dry deposition of $\mathrm{Hg}$ are essential in understanding the fate of $\mathrm{Hg}$ in the MBL.

\section{Acknowledgments}

This research was funded by the National Basic Research Program of China (No. 2013CB430002), National Natural Science Foundation of China (No. 41176066) and "Strategic Priority Research Program" of the Chinese Academy of Sciences, Grant No. XDB14020205. We gratefully acknowledge the open cruise in 2014 organized by the Ocean University of China (OUC). We thank the personnel from the OUC for their efforts. The technical assistance of the staff of the R/V Dongfanghong II (OUC) is gratefully acknowledged.

\section{References}

Amos, H.M., Jacob, D.J., Holmes, C.D., Fisher, J.A., Wang, Q., Yantosca, R.M., Corbitt, E.S., Galarneau, E., Rutter, A.P., Gustin, M.S., Steffen, A., Schauer, J.J., Graydon, J.A., St Louis, V.L., Talbot, R.W., Edgerton, E.S., Zhang, Y. Sunderland, E.M., 2012. Gas-particle partitioning of atmospheric $\mathrm{Hg}$ (II) and its effect on global mercury deposition. Atmos. Chem. Phys. 12, 591-603.

Ariya, P.A, Khalizov, A. Gidas, A, 2002. Reaction of gaseous mercury with atomic and molecular halogens: kinetics, products studies, and atmospheric implications. J. Phys. Chem. A 106, 7310-7320.

Ariya, P.A., Ryzhkov, A., 2003. Atmospheric transformation of elemental mercury upon reactions with halogens. J. Phys. IV Fr 107, 57-60.

Auzmendi-Murua, I., Castillo, Á., Bozzelli, J.W., 2014. Mercury oxidation via chlorine bromine, and iodine under atmospheric conditions: thermochemistry and kinetics. J. Phys. Chem. A 118, 2959-2975.

Bagnato, E., Sproveri, M., Barra, M., Bitetto, M., Bonsignore, M., Calabrese, S., Di Stefano, V., Oliveri, E., Parello, F., Mazzola, S., 2013. The sea-air exchange of mercury $(\mathrm{Hg})$ in the marine boundary layer of the Augusta basin (southern Italy): concentrations and evasion flux. Chemosphere 93, 2024-2032.

Calvert, J.G., Lindberg, S.E., 2005. Mechanisms of mercury removal by $\mathrm{O}_{3}$ and $\mathrm{OH}$ in the atmosphere. Atmos. Environ. 39, 3355-3367.

Chand, D., Jaffe, D., Prestbo, E., Swartzendruber, P.C., Hafner, W., Weiss-Penzias, P. Kato, S., Takami, A., Hatakeyama, S., Kajii, Y., 2008. Reactive and particulate mercury in the Asian marine boundary layer. Atmos. Environ. 42, 7988-7996.

Cheng, I., Zhang, L., Blanchard, P., Graydon, J.A., St Louis, V.L., 2012. Source-recepto relationships for speciated atmospheric mercury at the remote experimenta Lakes Area, northwestern Ontario, Canada. Atmos. Chem. Phys. 12, 1903-1922.

Cheng, I., Zhang, L., Blanchard, P., Dalziel, J., Tordon, R., 2013a. Concentrationweighted trajectory approach to identifying potential sources of speciated atmospheric mercury at an urban coastal site in Nova Scotia, Canada. Atmos. Chem. Phys. 13, 6031-6048.

Cheng, I., Zhang, L., Blanchard, P., Dalziel, J., Tordon, R., Huang, J., Holsen, T.M. 2013b. Comparisons of mercury sources and atmospheric mercury processes between a coastal and inland site. J. Geophys. Res. 118, 2434-2443. http://dx. doi.org/10.1029/2012JD018419.

Cheng, I., Zhang, L., Mao, H., Blanchard, P., Tordon, R., Dalziel, J., 2014. Seasonal and diurnal patterns of speciated atmospheric mercury at a coastal-rural and a coastal-urban site. Atmos. Environ. 82, 193-205.

Choi, H.D., Holsen, T.M., Hopke, P.K., 2008. Atmospheric mercury (Hg) in the adirondacks: concentrations and sources. Environ. Sci. Technol. 42, 5644-5653.

Ci, Z., Wang, C., Wang, Z., Zhang, X., 2015. Elemental mercury $(\operatorname{Hg}(0))$ in air and surface waters of the Yellow Sea during late spring and late fall 2012: concentration, spatial-temporal distribution and air/sea flux. Chemosphere 119, 199-208.

Engle, M.A., Tate, M.T., Krabbenhoft, D.P., Kolker, A., Olson, M.L., Edgerton, E.S., DeWild, J.F., McPherson, A.K., 2008. Characterization and cycling of atmospheric mercury along the central US Gulf Coast. Appl. Geochem 23, 419-437.

Ferrara, R., Mazzolai, B., Lanzillotta, E., Nucaro, E., Pirrone, N., 2000. Volcanoes as emission sources of atmospheric mercury in the Mediterranean basin. Sci. Total Environ. 259, 115-121.

Fu, X., Feng, X., Zhang, G., Xu, W., Li, X., Yao, H., Liang, P., Li, J., Sommar, J., Yin, R., Liu, N., 2010. Mercury in the marine boundary layer and seawater of the South China Sea: concentrations, sea/air flux, and implication for land outflow. J. Geophys. Res. 115, D06303. http://dx.doi.org/10.1029/2009JD012958.

Fu, X., Feng, X., Qiu, G., Shang, L., Zhang, H., 2011. Speciated atmospheric mercury and its potential source in Guiyang, China. Atmos. Environ. 45, 4205-4212.

Fu, X., Feng, X., Liang, P., Deliger, Zhang, H., Ji, J., Liu, P., 2012. Temporal trend and sources of speciated atmospheric mercury at Waliguan GAW station, Northwestern China. Atmos. Chem. Phys. 12, 1951-1964.

Gabriel, M.C., Williamson, D.G., Brooks, S., Lindberg, S., 2005. Atmospheric speciation of mercury in two contrasting Southeastern US airsheds. Atmos. Environ. 39, 4947-4958.

Gustin, M.S., Amos, H.M., Huang, J., Miller, M.B., Heidecorn, K., 2015. Measuring and modeling mercury in the atmosphere: a critical review. Atmos. Chem. Phys. 15 5697-5713.

Hedgecock, I., Pirrone, N., 2001. Mercury and photochemistry in the marine boundary layer-modelling studies suggest the in situ production of reactive gas phase mercury. Atmos. Environ. 35, 3055-3062.

Hedgecock, I.M., Pirrone, N., Sprovieri, F., Pesenti, E., 2003. Reactive gaseous mercury in the marine boundary layer: modeling and experimental evidence of its formation in the Mediterranean region. Atmos. Environ. 37, S41-S49.

Holmes, C.D., Jacob, D.J., Mason, R.P., Jaffe, D.A., 2009. Sources and deposition of reactive gaseous mercury in the marine atmosphere. Atmos. Environ. 43, $2278-2285$.

Holmes, C.D., Jacob, D.J., Corbitt, E.S., Mao, J., Yang, X., Talbot, R., Slemr, F., 2010. Global atmospheric model for mercury including oxidation by bromine atoms. Atmos. Chem. Phys. 10, 12037-12057.

Huang, J., Gustin, M.S., 2015. Uncertainties of gaseous oxidized mercury measurements using $\mathrm{KCl}$-coated denuders, cation-exchange membranes, and nylon membranes: humidity influences. Environ. Sci. Technol. 49, 6102-6108.

Kim, S.H., Han, Y.J., Holsen, T.M., Yi, S.M., 2009. Characteristics of atmospheric speciated mercury concentrations (TGM, $\mathrm{Hg}(\mathrm{II})$ and $\mathrm{Hg}(\mathrm{p})$ ) in Seoul, Korea. Atmos. Environ. 43, 3267-3274.

Kim, P.R., Han, Y.J., Holsen, T.M., Yi, S.M., 2012. Atmospheric particulate mercury: concentrations and size distributions. Atmos. Environ. 61, 94-102.

Landis, M.S., Stevens, R.K., Schaedlich, F., Prestbo, E.M., 2002. Development and characterization of an annular denuder methodology for the measurement of divalent inorganic reactive gaseous mercury in ambient air. Environ. Sci. Technol. 36, 3000-3009.

Laurier, F.J.G., Mason, R.P., Whalin, L., Kato, S., 2003. Reactive gaseous mercury formation in the North Pacific Ocean's marine boundary layer: a potential role of halogen chemistry. J. Geophys. Res. 108, 4529. http://dx.doi.org/10.1029/ 2003JD003625.

Laurier, F., Mason, R., 2007. Mercury concentration and speciation in the coastal and 
open ocean boundary layer. J. Geophys. Res. 112, D06302. http://dx.doi.org/10. 1029/2006JD007320.

Lin, C.J., Pan, L., Streets, D.G., Shetty, S.K., Jang, C., Feng, X., Chu, H.W., Ho, T.C., 2010. Estimating mercury emission out-flow from East Asia using CMAQ-Hg. Atmos. Chem. Phys. 10, 1853-1864.

Lindberg, S.E., Brooks, S., Lin, C.J., Scott, K.J., Landis, M.S., Stevens, R.K., Goodsite, M., Richter, A., 2002. Dynamic oxidation of gaseous mercury in the Arctic troposphere at polar sunrise. Environ. Sci. Technol. 36, 1245-1256.

Liu, B., Keeler, G.J., Dvonch, J.T., Barres, J.A., Lynam, M.M., Marsik, F.J., Morgan, J.T., 2007. Temporal variability of mercury speciation in urban air. Atmos. Environ. 41, 1911-1923.

Liu, B., Keeler, G.J., Dvonch, J.T., Barres, J.A., Lynam, M.M., Marsik, F.J., Morgan, J.T., 2010. Urban-rural differences in atmospheric mercury speciation. Atmos. Environ. 44, 2013-2023.

Liu, N., Qiu, G., Landis, M., Feng, X., Fu, X., Shang, L., 2011. Atmospheric mercury species measured in Guiyang, Guizhou province, southwest China. Atmos. Res. 100, 93-102.

Lyman, S.N., Jaffe, D.A., Gustin, M.S., 2010. Release of mercury halides from $\mathrm{KCl}$ denuders in the presence of ozone. Atmos. Chem. Phys. 10, 8197-8204.

Malcolm, E.G., Keeler, G.J., 2007. Evidence for a sampling artifact for particulatephase mercury in the marine atmosphere. Atmos. Environ. 41, 3352-3359.

Mao, H., Talbot, R., 2012. Speciated mercury at marine, coastal, and inland sites in New England - part 1: temporal variability. Atmos. Chem. Phys. 12, 5099-5112.

Mao, H., Talbot, R., Hegarty, J., Koermer, J., 2012. Speciated mercury at marine, coastal, and inland sites in New England - part 2: relationships with atmospheric physical parameters. Atmos. Chem. Phys. 12, 4181-4206.

Mason, R.P., Sheu, G.R., 2002. Role of the ocean in the global mercury cycle. Global Biogeochem. Cycles 16 (1093). http://dx.doi.org/10.1029/2001GB001440.

Mason, R.P., Choi, A.L., Fitzgerald, W.F., Hammerschmidt, C.R., Lamborg, C.H., Soerensen, A.L., Sunderland, E.M., 2012. Mercury biogeochemical cycling in the ocean and policy implications. Environ. Res. 119, 101-117.

Pacyna, E.G., Pacyna, J.M., 2002. Global emission of mercury from anthropogenic sources in 1995. Water Air Soil Pollut. 137, 149-165.

Pacyna, J.M., Pacyna, E.G., Steenhuisen, F., Wilson, S., 2003. Mapping 1995 global anthropogenic emissions of mercury. Atmos. Environ. 37, S109-S117.

Pacyna, E.G., Pacyna, J.M., Steenhuisen, F., Wilson, S., 2006. Global anthropogenic mercury emission inventory for 2000. Atmos. Environ. 40, 4048-4063.

Pacyna, E.G., Pacyna, J.M., Sundseth, K., Munthe, J., Kindbom, K., Wilson, S., Steenhuisen, F., Maxson, P., 2010. Global emission of mercury to the atmosphere from anthropogenic sources in 2005 and projections to 2020. Atmos. Environ. 44, 2487-2499.

Pal, B., Ariya, P.A., 2004a. Gas-phase HO center dot-initiated reactions of elemental mercury: kinetics, product studies, and atmospheric implications. Environ. Sci. Technol. 38, 5555-5566.

Pal, B., Ariya, P.A., 2004b. Studies of ozone initiated reactions of gaseous mercury: kinetics, product studies, and atmospheric implications. Phys. Chem. Chem. Phys. 6, 572-579.

Pirrone, N., Cinnirella, S., Feng, X., Finkelman, R.B., Friedli, H.R., Leaner, J., Mason, R., Mukherjee, A.B., Stracher, G.B., Streets, D.G., Telmer, K., 2010. Global mercury emissions to the atmosphere from anthropogenic and natural sources. Atmos. Chem. Phys. 10, 5951-5964.

Poissant, L., Pilote, M., Xu, X., Zhang, H., 2004. Atmospheric mercury speciation and deposition in the Bay St. François wetlands. J. Geophys. Res. 109, D11301. http:// dx.doi.org/10.1029/2003JD004364.

Radke, L.F., Friedli, H.R., Heikes, B.G., 2007. Atmospheric mercury over the NE Pacific during spring 2002: gradients, residence time, upper troposphere lower stratosphere loss, and long-range transport. J. Geophys. Res. 112, D19305. http:// dx.doi.org/10.1029/2005JD005828.

Rutter, A.P., Schauer, J.J., 2007. The effect of temperature on the gas-particle partitioning of reactive mercury in atmospheric aerosols. Atmos. Environ. 41, $8647-8657$.

Rutter, A.P., Hanford, K.L., Zwers, J.T., Perillo-Nicholas, A.L., Schauer, J.J., Olson, M.L., 2008. Evaluation of an offline method for the analysis of atmospheric reactive gaseous mercury and particulate mercury. J. Air Waste Manag. Assoc. 58, $377-383$.

Sander, R., Keene, W.C., Pszenny, A.A.P., Arimoto, R., Ayers, G.P., Baboukas, E., Cainey, J.M., Crutzen, P.J., Duce, R.A., Hönninger, G., Huebert, B.J., Maenhaut, W., Mihalopoulos, N., Turekian, V.C., Van Dingenen, R., 2003. Inorganic bromine in the marine boundary layer: a critical review. Atmos. Chem. Phys. 3, 1301-1336.

Schroeder, W.H., Munthe, J., 1998. Atmospheric mercury - an overview. Atmos. Environ. 32, 809-822.

Seigneur, C., Lohman, K., 2008. Effect of bromine chemistry on the atmospheric mercury cycle. J. Geophys. Res. 113, D23309. http://dx.doi.org/10.1029/ 2008JD010262.

Selin, N.E., Jacob, D.J., Park, R.J., Yantosca, R.M., Strode, S., Jaeglé, L., Jaffe, D., 2007. Chemical cycling and deposition of atmospheric mercury: global constraints from observations. J. Geophys. Res. 112, D02308. http://dx.doi.org/10.1029/
2006JD007450.

Sheu, G.R., Mason, R.P., 2004. An examination of the oxidation of elemental mercury in the presence of halide surfaces. J. Atmos. Chem. 48, 107-130.

Soerensen, A.L., Skov, H., Jacob, D.J., Soerensen, B.T., Johnson, M.S., 2010. Globa concentrations of gaseous elemental mercury and reactive gaseous mercury in the marine boundary layer. Environ. Sci. Technol. 44, 7425-7430.

Soerensen, A.L., Mason, R.P., Balcom, P.H., Sunderland, E.M., 2013. Drivers of surface ocean mercury concentrations and air-sea exchange in the West Atlantic Ocean. Environ. Sci. Technol. 47, 7757-7765.

Soerensen, A.L., Mason, R.P., Balcom, P.H., Jacob, D.J., Zhang, Y., Kuss, J., Sunderland, E.M., 2014. Elemental mercury concentrations and fluxes in the tropical atmosphere and ocean. Environ. Sci. Technol. 48, 11312-11319.

Sprovieri, F., Pirrone, N., Gärdfeldt, K., Sommar, J., 2003. Mercury speciation in the marine boundary layer along a $6000 \mathrm{~km}$ cruise path around the Mediterranean Sea. Atmos. Environ. 37, S63-S71.

Sprovieri, F., Pirrone, N., 2008. Spatial and temporal distribution of atmospheric mercury species over the Adriatic Sea. Environ. Fluid Mech. 8, 117-128.

Sprovieri, F., Hedgecock, M., Pirrone, N., 2010. An investigation of the origins of reactive gaseous mercury in the Mediterranean marine boundary layer. Atmos. Chem. Phys. 10, 3985-3997.

Steffen, A., Lehnherr, I., Cole, A., Ariya, P., Dastoor, A., Durnford, D., Kirk, J., Pilote, M., 2015. Atmospheric mercury measurements in the Canadian Arctic Part 1: a review of recent field measurements. Sci. Total Environ. 509-510, 3-15.

Streets, D.G., Hao, J., Wu, Y., Jiang, J., Chan, M., Tian, H., Feng, X., 2005. Anthropogenic mercury emissions in China. Atmos. Environ. 39, 7789-7806.

Strode, S.A., Jaeglé, L., Selin, N.E., Jacob, D.J., Park, R.J., Yantosca, R.M., Mason, R.P., Slemr, F., 2007. Air-sea exchange in the global mercury cycle. Glob. Biogeochem. Cycles 21, GB1017. http://dx.doi.org/10.1029/2006GB002766.

Talbot, R., Mao, H., Feddersen, D., Smith, M., Kim, S.Y., Sive, B., Haase, K., Ambrose, J., Zhou, Y., Russo, R., 2011. Comparison of particulate mercury measured with manual and automated methods. Atmosphere 2, 1-20.

Tekran, 2008. Model 2537B Ambient Mercury Vapour Analyzer User Manual. Canada, Toronto.

Tseng, C.M., Liu, C.S., Lamborg, C., 2012. Seasonal changes in gaseous elemental mercury in relation to monsoon cycling over the northern South China Sea. Atmos. Chem. Phys. 12, 7341-7350.

Valente, R.J., Shea, C., Lynn Humes, K., Tanner, R., 2007. Atmospheric mercury in the Great Smoky Mountains compared to regional and global levels. Atmos. Environ. $41,1861-1873$.

Wan, Q., Feng, X., Lu, J., Zheng, W., Song, X., Li, P., Han, S., Xu, H., 2009. Atmospheric mercury in Changbai Mountain area, northeastern China II. The distribution of reactive gaseous mercury and particulate mercury and mercury deposition fluxes. Environ. Res. 109, 721-727.

Wang, Z., Pehkonen, S.O., 2004. Oxidation of elemental mercury by aqueous bromine: atmospheric implications. Atmos. Environ. 38, 3675-3688.

Wang, S., Schmidt, J.A., Baidar, S., Coburn, S., Dix, B., Koenig, T.K., Apel, E., Bowdalo, D., Campos, T.L., Eloranta, E., Evans, M.J., DiGangi, J.P., Zondlo, M.A. Gao, R., Haggerty, J.A., Hall, S.R., Hornbrook, R.S., Jacob, D., Morley, B., Pierce, B., Reeves, M., Romashkin, P., ter Schure, A., Volkamer, R., 2015. Active and widespread halogen chemistry in the tropical and subtropical free troposphere. Proc. Natl. Acad. Sci. U.S.A. 112 (30), 9281-9286.

Wang, C., Wang, Z., Ci, Z., Zhang, X., Tang, X., 2016. Spatial-temporal distributions of gaseous element mercury and particulate mercury in the Asian marine boundary layer. Atmos. Environ. 126, 107-116.

Weiss-Penzias, P., Jaffe, D.A., McClintick, A., Prestbo, E.M., Landis, M.S., 2003. Gaseous elemental mercury in the marine boundary layer: evidence for rapid removal in anthropogenic pollution. Environ. Sci. Technol. 37, 3755-3763.

Weiss-Penzias, P., Gustin, M.S., Lyman, S.N., 2009. Observations of speciated atmospheric mercury at three sites in Nevada: evidence for a free tropospheric source of reactive gaseous mercury. J. Geophys. Res. 114, D14302. http://dx.doi. org/10.1029/2008JD011607.

Witt, M.L.I., Mather, T.A., Baker, A.R., De Hoog, J.C.M., Pyle, D.M., 2010. Atmospheric trace metals over the south-west Indian Ocean: total gaseous mercury, aeroso trace metal concentrations and lead isotope ratios. Mar. Chem. 121, 2-16.

Wu, Y., Wang, S., Streets, D.G., Hao, J., Chan, M., Jiang, J., 2006. Trends in anthropogenic mercury emissions in China from 1995 to 2003. Environ. Sci. Technol. 40, 5312-5318.

Xu, L., Chen, J., Yang, L., Niu, Z., Tong, L., Yin, L., Chen, Y., 2015. Characteristics and sources of atmospheric mercury speciation in a coastal city, Xiamen, China. Chemosphere 119, 530-539.

Zhang, X., Siddiqi, Z., Song, X., Mandiwana, K.L., Yousaf, M., Lu, J., 2012. Atmospheric dry and wet deposition of mercury in Toronto. Atmos. Environ. 50, 60-65.

Zhang, L., Wang, S., Wang, L., Wu, Y., Duan, L., Wu, Q., Wang, F., Yang, M., Yang, H., Hao, J., Liu, X., 2015. Updated emission inventories for speciated atmospheric mercury from anthropogenic sources in China. Environ. Sci. Technol. 49, 3185-3194. 